\title{
THE FOOD CULTURE IN DEVELOPMENT \\ OF RURAL TOURISM IN HERZEGOVINA
}

\author{
Željka Šiljković $^{18}$ \\ Marica Mamut ${ }^{19}$ \\ Jelena Putica ${ }^{20}$
}

\begin{abstract}
Gastronomy is an important part of rural tourism and in all its authenticity is a part of the immaterial cultural heritage of a particular region or a local community.

Gastronomic tours are specific tourist products that represent some areas in the international tourist market, for example cheese, wine and olive roads.

Among the numerous tourists visiting Herzegovina and the Adriatic coast every year, there are so-called Existential tourists whose aim is to taste and feel the authenticity of the Herzegovinian area and it's gastronomic culture.

Tasting food in authentic rural areas is a kind of ritual for getting to know the history and cultural heritage of the local community. Each dish has its own story and origin.

Modern rural tourism promotes specific food and wine destinations through the Internet, specialized travel agencies, smartphone applications and the media. Electronic media, like television, play a big role in promoting the gastronomy and the culinary world, through special programs and channels.

Herzegovina has preserved numerous traditional meals, primarily by word of mouth, but in reality only a few meals (japra and dolma, pancakes, sour polenta, meals under the sač) are recognizable. The authenticity of the area represents a significant tourist potential by incorporating traditional meals into the restaurants offer, family farms and the opening of food and wine roads, as well as the tourist's active participation in the preparation of food.

The article analyzes the existing conditions of gastro tourism in the rural areas of Herzegovina. The survey was conducted at the level of owners of touristic facilities, tourists and local residents. By using the interview method it was attempted to determine if the local population was preserving the tradition of autochthonous food.
\end{abstract}

Key words: gastronomy, rural tourism, traditional meals, promotion, Herzegovina

\section{INTRODUCTION}

Every country in the world has its own unique gastronomic tradition and personality. Gastronomy is an important part of the cultural heritage of each region and state.

The Committee on Culture and Education of the European Parliament approved the adoption of a resolution of "European gastronomic heritage: a cultural and educational aspect". Food and gastronomy are recognized as part of artistic and cultural expression,

\footnotetext{
${ }^{18}$ Full professor, Department of Geography, University of Zadar, Zadar, Croatia

${ }^{19}$ Phd, Assistant professor, Department of Geography, University of Zadar, Zadar, Croatia

${ }^{20}$ Assistant, Department of Geography, Faculty of Science and Education, University of

Mostar, Mostar, Bosnia and Herzegovina
} 
and as an integral part of social relations in the family and society (Cavicchi, Stancova, 2014: 6).

Food has a great sociological significance, since it touches the local population and tourists, people of different ages, gender, religious affiliations, different cultural traditions and habits, as well as a different social status (Cavicchi, Stancova, 2016).

The gastronomy conveys knowledge, information about people and culture. Thanks to gastronomy we recognize the identity of a particular destination. (Jimenez - Beltram, 2016).The concept of "Foodscarves" (Cavicchi, Stancova, 2016) integrates local culture, tradition and food, which becomes a significant factor in linking authenticity at the local and global level.

This creates the idea of glocarization by which local products become globally recognizable.

Mass forms of tourism, and food globalization, lead to the saturation of globally recognizable food and search for an autochthonous original product.

Today, the globalization of the food industry has caused increasing acceptance of the mainstream in nutrition, ignoring and neglecting its own gastronomy in the region or the state. Saturated by foods of various pizzerias, MC Donalds, KFCs, Starbucks, Burger Kings or Sunway, gastronomists reveal forgotten dishes, explore small local inns and taste old dishes. Gastroturizam allows a certain area to "live in tourism" all year, encourages the opening of family farms and opens jobs to local people. At the same time, there is an increase in the number of tourists who spend almost a third of their resources on food (Quan, Wang, 2004). Gastroturist does not seek an industrial monotonous landscape. In this way, the awareness of the local population is also enhanced to preserve cultural heritage and traditional customs (Drpić - Vukman, 2014). Gastroturizam, as an integral part of cultural tourism, explores the culture and history of a certain area (Long, 2004, Kalenjuk at all., 2013).

The food of an area has its own genesis of origin, a story of its origin through which one can perceive a wider geographic image of space, its natural - geographical features, such as climate, soil or relief, as well as sociological and cultural characteristics.

\section{GASTROTURISM AND BRANDING DESTINATION}

Gastro-tourism plays an important role in branding destination. According to Richards (2015), food is a part of destination marketing because it allows tourists to get to know the destination by contact with the local culture.

Eating habits differ in certain cultural communities, depending on the time of their diet, the way they eat and what they eat. Food is used to recognize the landscape from which the ingredients originate. This is done through the research, recognition and education of tourists. According to Hall and Sharples (2008) and Hall (2012) there are several touch points that link the public and private interests of gastronomy - tourism and branding. 
1. Gastroturists are high-income tourists

2. Gastro-tourism is closely linked to other tourism products, such as culture and / or natural attractions

3. Gastroturizam opens the possibilities for development of individual urban districts with autochthonous cuisine

4. Food becomes synonymous with a geographical location through which the cultural features of the space are recognized

Today there are numerous tour operators who have focused on gourmet tourist tours around the world and organize trips that include (Hall (2012):

- Cooking schools

- Dining in elite restaurants at elite locations

- Visits to farmers' markets

- Visits to food manufacturers

- Or more frequent tours of street food

Tikkanen (2007) thinks that there are five main motives driven by gastro tourists (Williams, Williams,. and Omar, 2014):

- Food is an attraction

- Foods are a product that gastro tourists consume

- The value of food is in taste and smell

- Food is perceived as a cultural phenomenon

- There is a multiple benefit by linking tourism and local food producers

Today, digital communication is an indispensable part of deciding on a travel trip. Online communications, such as Facebook, Twiter, Trip Advisor, Booking.com or blogs, have an important, crucial role in choosing a travel destination and in expressing opinions, perceptions of destination, discussion and feedback (Kempiak, at all., 2012 .). The Internet is a common global tool for promoting the destination both by tourists and by the destination itself. Photos of destination, photos of food and photos of local autochthonous restaurants, through social networks, are exchanging. This is very important for gastronomic tourists (Kempiak, at. All., 2012). The gastronomy of Herzegovina can also be found in the application of Taste of Herzegovina, through which tourists can find out about traditional food products („Livno“ cheese, cheese „Shkripavac“,collard greens named „rashtika“, asparagus, rose hip. The product descriptions mention the location of the space for which a certain space is bound) .

Local food tourists more often bring to homes, as some kind of souvenirs, to meet their neighbors. Some souvenirs can be purchased at local markets, on family farms or along 
the main roads. That souvenirs (such us food) are not specially designed or specially packed. They are completely indigenous. Such cheeses or honey that are sold along the road in Herzegovina, but also fruits, such as pomegranate, mandarins, figs, grapes, or specially homemade garlic on the thread. These souvenirs are mainly used for personal use. Another type of souvenir is those that tourists buy as gifts for friends or family. They are specially designed, branded and purchased in specialized stores of local delicacies or souvenir shops (wine such as Blatina, Žilavka, flavored brandy, liqueurs and etc.).

\section{GASTROTURISM OF HERZEGOVINA}

Herzegovina is a region located in the southern part of Bosnia and Herzegovina. Despite its specific cuisine, it is still not sufficiently recognized on the gastronomic map of the world. Today's kitchen originates from the earlier cultures and civilizations of the people who lived in this area, and whose heritage has survived to this day.

In the Bosnian-Herzegovinian cuisine intertwine the customs and traditions of Christianity, Islam, Judaism and all the peoples who lived for centuries. Therefore, the Bosnian - Herzegovinian gastronomy is a part of cultural heritage and belongs to cultural tourism (Halilović - Šarić, 2015). Food is changing from region to region, depending on the natural and social characteristics of the region. At the same time, the diet differs in the summer and winter. Food of the rural and urban population are also different, and the social status of the family in society also affects the type of diet (Alibabić at. All, 2012).

Over time some meals have disappeared, and some have acquired a wider, even global significance. The most popular are barbecue meals, such as kebabs.

The food, which is a kind of brand of Bosnia and Herzegovina and which has expanded, and has hosted in neighboring countries, is a burek, who comes to this area around 1462 from Persia (Alibabić at all, 2012).

Herzegovina's gastronomy consists of: salty and sweet meals, sweets, liqueurs, wines. From salty meals in the kitchen of Herzegovina are dominated different types of soup (Collorad greens, Herzegovinian pot, sour cabbage), which are prepared mainly with meat, with light cooking and mild spices (ground pepper, pepper, parsley, celery (Pervan, 2013). A special part of Hezegovina's gastronomy is cold meals, mainly consisting of prosciutto, various types of cheeses, pancakes, etc. Apart from the soup, the Herzegovina's gastronomy is also known for the lamb that is baked on the open fire, and roast lamb can be found in specialized restaurants along the main roads (Udovice Mostar-Čitluk, Zdrava voda Jablanica-Sarajevo etc.). An inseparable part of Herzegovina's gastronomy is pura or palenta, most often made with sour milk, butter and garlic (Fig. 1.) Previously she was cooking in wooden dishes and mixed with special wooden spoons, called mixers. Pura originates from the Italian gastronomy and 
imported from Dalmatia to the territory of Herzegovina, and for a long time it is one of the main food of this region.

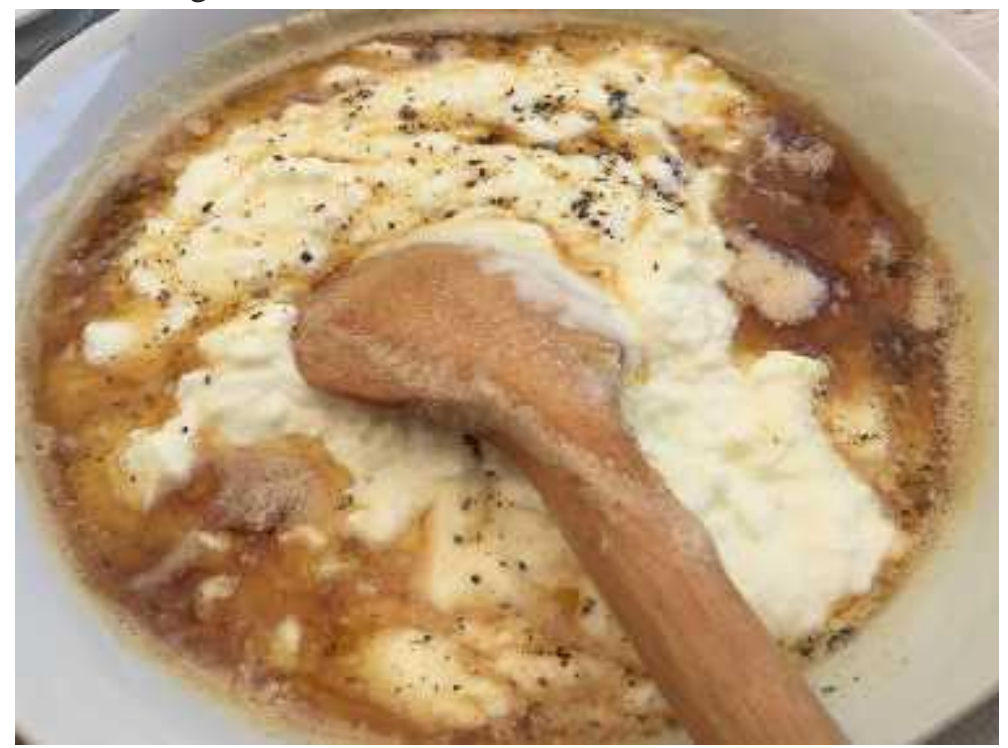

Fig. 1. Pura with sour milk

Source: Putica, restaurant Borak Široki Brijeg, July, 2017.

An integral part of all Herzegovinian meals is bread, and especially important is the one cooked traditionally under the sach. Region of Herzegovina is famous in the world for the cultivation of grapevines, especially indigenous varieties Žilavka and Blatina, from them have prepared quality wines. One of the most valued stone wines have produced in the area of Brotnjo. Herzegovina can be divided regionally into two parts: the region of the Low and High Herzegovina. These two parts are different in physical and geographical characteristics (relief, climate and soil). They differ because of different culinary habits, which means that natural geographical conditions have determined and shaped the traditional Herzegovinian cuisine.The gastronomy of the High Herzegovina (Rakitno, Risovac) have based on the production of dairy products (,cheese in a sack“ made from „mijeh“21, Škripavac cheese, butter, pork rind) and meat products

\footnotetext{
${ }^{21}$ Cheese in a sack / "mijeh" cheese -is one of the oldest dishes whose source connects with the nomadic Illyrian and Thracian tribes in the mountain and mountain regions of Dalmatian Zagora, Lika, Velebit, Herzegovina. It has made in the areas where livestock breeding, primarily sheep and goat farming, was the main economic activity. In the neighboring Republic of Croatia, this cheese received the status of an intangible cultural heritage (Ministry of Culture, December $20,2007)$. Today it has been producing from sheep, goat, cow milk and is not producing in an industrial way, it is producing only from domestic milk from 22 farms. Cheese is keeping in lamb skin ("mijeh") for two to three months and has a strong smell and aroma (Kalit,2016).It is a gastronomic product, former cattle dessert, and today it is a delicacy for tourists who are ready to dedicate more money for that product. With the cheese one more specificity of Herzegovina is sour cream named " kajmak".aroma (Kalit,2016).It is a gastronomic product, former cattle
} 
(prosciutto, pancetta). The area of High Herzegovina is known for baking various types of brandy, the most famous is one which is obtained by fermentation and distillation of plum juice. Traditionally, this area is known for the production of apple and plum jam.

The cuisine of Low Herzegovina is known for fruit. From fruits various biscuits are making,such as dessert of fig named „smokvara“, Sponge cake named ,patišpanja“, homemade cake of puff pastry named "salenjaka", hurmashica, tufahia, apple pie, cherries and carobs pie. Part of the sweet dishes like hurmashica and tufahia have roots in Turkish gastronomy, while patispanj ("Pan di Spanga") brought Dubrovnik sailors from Spain to these parts. From southern Dalmatia it spread to surrounding regions, which today have considered a traditional cake (Montenegrin patishpanj, Dubrovnik patishpanj, Istrian patishpanj, Bosnian nutma or lutma). The space of the Low Herzegovina, ie. the ends along the Trebižat and Neretva rivers (Ljubuški, Čapljina) are also characteristic for cooking frogs, river crubs, eels and fish soup. (Fig. 2.)

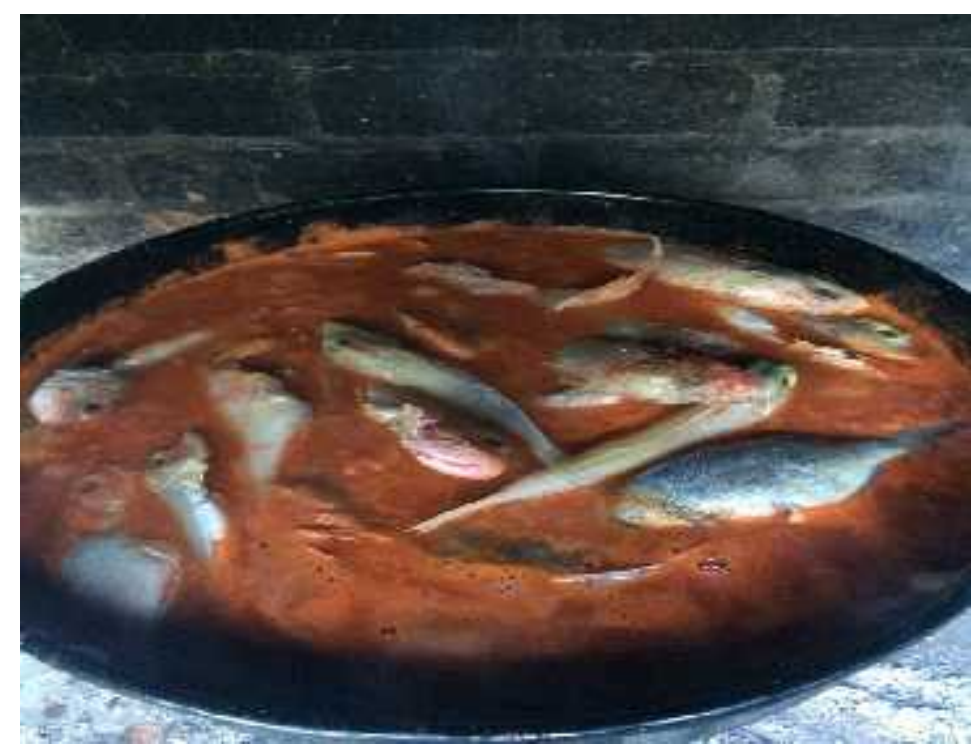

Fig. 2. Brudet

Source: Perutina, valley Neretva, june, 2017.

Rural areas of Herzegovina are known for traditional food preparation, such as slaughtering pigs, wintering and brandy production.In the earlier time winter stores prepared for the need and lack of vegetables in the winter months, but nowadays they mostly prepared for fostering tradition and transferring customs to younger generations. Most of the meals recipes is transferring from the knee to the knee.

dessert, and today it is a delicacy for tourists who are ready to dedicate more money for that product. With the cheese one more specificity of Herzegovina is sour cream named "kajmak" 
Unfortunately, there is no significant work that would include a historical overview of Herzegovinian gastronomy, but it is important to emphasize that a few books of traditional recipes in these regions have been issued in the area of the region.

Gastronomic manifestations are positive example of the promotion of Herzegovina and also the preservation of customs and tradition. Local autochthonous gastronomic products are presented to visitors, as well as the way of preparing certain dishes, which are very often different from place to place. Gastro manifestations alongside food combine different tourist products, such as (dances, songs, souvenirs).

Since in the area of Herzegovina is the largest number of visits recorded in the summer months, the most significant gastronomic events are held just outside the summer season in order to attract a certain number of tourists. The calendar of the most important gastronomic events in Herzegovina is shown in Table 1.

Table 1. Calendar of gastronomic events in Herzegovina

\begin{tabular}{|l|l|l|}
\hline City & Maintenance & Month of maintenance \\
\hline Bileća & Cicvariada & June \\
\hline Čitluk & Days of harvest grape & September \\
\hline Grude & Collard maintenance & October \\
\hline Mostar & Fair of chocolate and delicacies & April \\
\hline Prozor & Days of plum & September \\
\hline Stolac & $\begin{array}{l}\text { Herzegovinian fruits of the } \\
\text { Mediterranean }\end{array}$ & September \\
\hline Široki Brijeg & BH Dukat Taste Herzegovina & November \\
\hline Trebinje & Days of wine and honey in Trebinje & August \\
\hline Trebinje & Days of open wine cellars & December \\
\hline
\end{tabular}

Source: Autors, june, 2017.

\section{RESEARCH}

The paper analyzes the existing state of gastroturism in Herzegovina with an emphasis on rural areas. The aim of the research is to determine the extent to which some traditional gastronomic products are represented in the offer of catering facilities. The research also established the satisfaction of tourists with a gastronomic offer on the territory of Herzegovina.

The survey was conducted on the following questionnaire:

a) Owners of tourist facilities 
The survey questionnaire included 17 tourist catering facilities in Herzegovina. The questionnaire contained 15 closed-type questions and the survey conducted from June to September 2017, via an on-line questionnaire.

b) Tourists (80)

The questionnaire also contained 15 closed-type questions, and the survey conducted from June to September 2017 in the area of Western Herzegovina. (Mostar, Medjugorje, Široki Brijeg, Ljubuški). The collected data are processed using the Excel program software.

\section{RESULTS}

The first part of the survey relates to the analysis of catering facilities in the territory of Herzegovina.According to the type of catering facilities, $55 \%$ of the facilities are restaurants and taverns, $30 \%$ of the facilities are agrotourism, $10 \%$ are ethno and 5\% are eco villages. (Table 2. Fig. 3.)

Table 2. Structure of analyzed tourist facilities

\begin{tabular}{|l|l|l|l|}
\hline \multicolumn{4}{|l|}{ Analyzed catering facilities } \\
\hline Place & Restaurant & Taverns & Tourist facilities of rural tourism \\
\hline Buna & 1 & & \\
\hline Čapljina & & & 1 \\
\hline Grude & & & 1 \\
\hline Konjic & 1 & & 1 \\
\hline Ljubuški & 1 & 1 & \\
\hline Međugorje & & & 2 \\
\hline Neum & & & 2 \\
\hline Risovac & 1 & 1 & \\
\hline Ravno & 2 & 1 & \\
\hline Široki Brijeg & 1 & & \\
\hline
\end{tabular}

Source: Putica, according to the survey, 2017. 


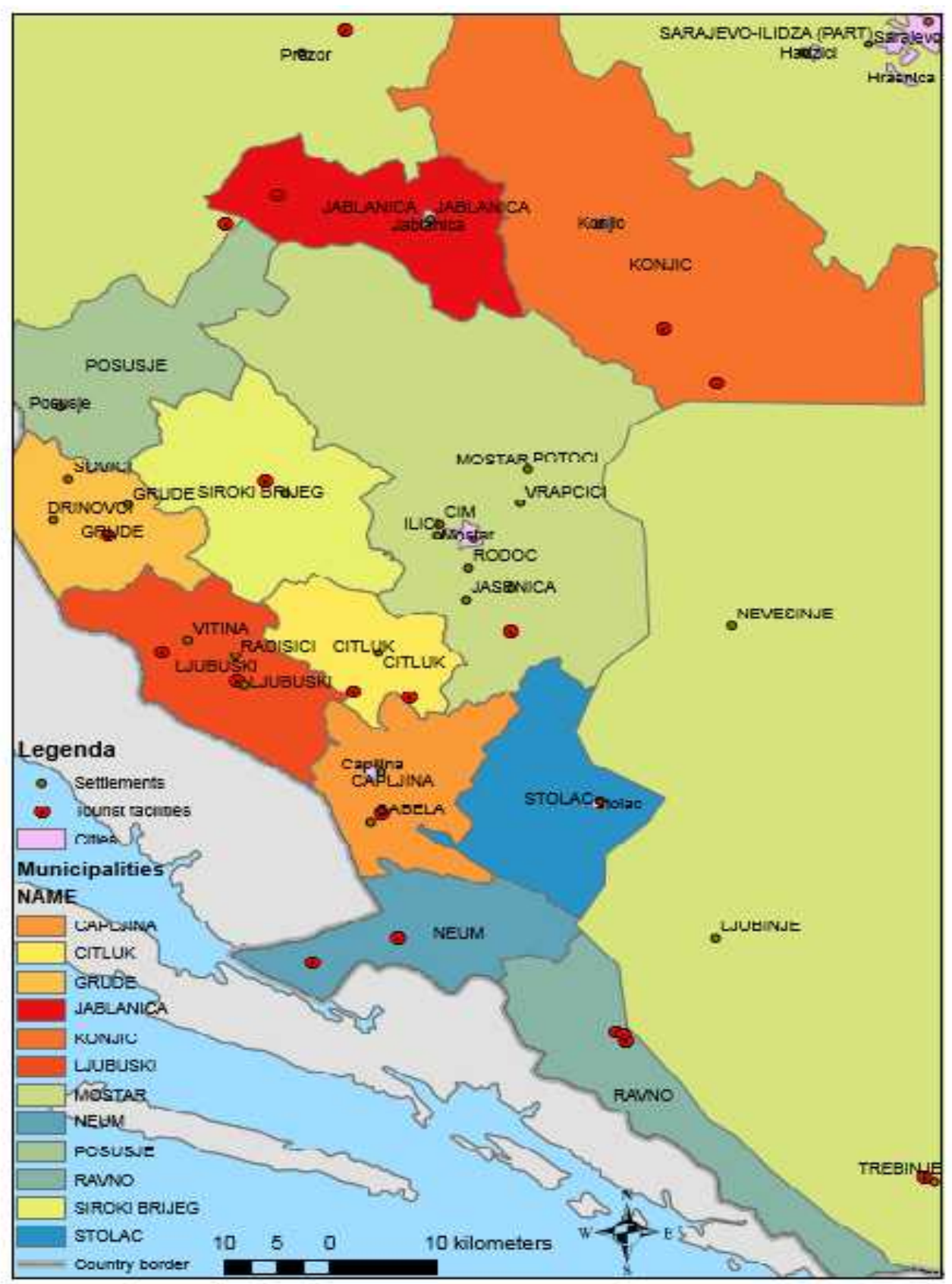

Fig. 3. Cartographic presentation of analyzed tourist facilities Source: Putica, according to surveys, 2017.

Considering the elements of tourist offer in catering facilities, most of them (38\%) offer guests only food services. The reason for this is that rural tourism in the area of Herzegovina still has only an excursion character. Tourists visit the property, taste traditional specialties, but do not stay in the buildings for more than a few hours. 58\% of the analyzed facilities in the catering industry also deal with the cultivation of 
agricultural crops (fruits, vegetables) and the storage of traditional gastronomic products (cheeses, liqueurs, honey, etc.). The results of the research related to the promotion of catering facilities show that everyone uses the Internet as a way of promotion but also other media like television and radio.

In addition to the mentioned media used for promotion, one part of the facilities also promotes 25\% of them at fairs (Mostar Fair, Plum Days in Prozor, Trebinje Days of Wine and Honey). Following the new tourist trends (the return of man to nature, greater contact with hosts), $44 \%$ of the agrotouristic facilities offer the possibility of so-called. "Self-service" where guests can participate themselves in housework. Agrotourist farms in the area of Herzegovina offer opportunities to participate in harvesting vineyards, making fruit liqueurs and various kinds of cheese etc. In the last ten years, some owners of agrotourist farms also cultivate medicinal herbs (curry plant -“smilje", lavender, rosemary) from which souvenir products are made, which with a bigger promotion can become one of the brands of rural tourism in Herzegovina.

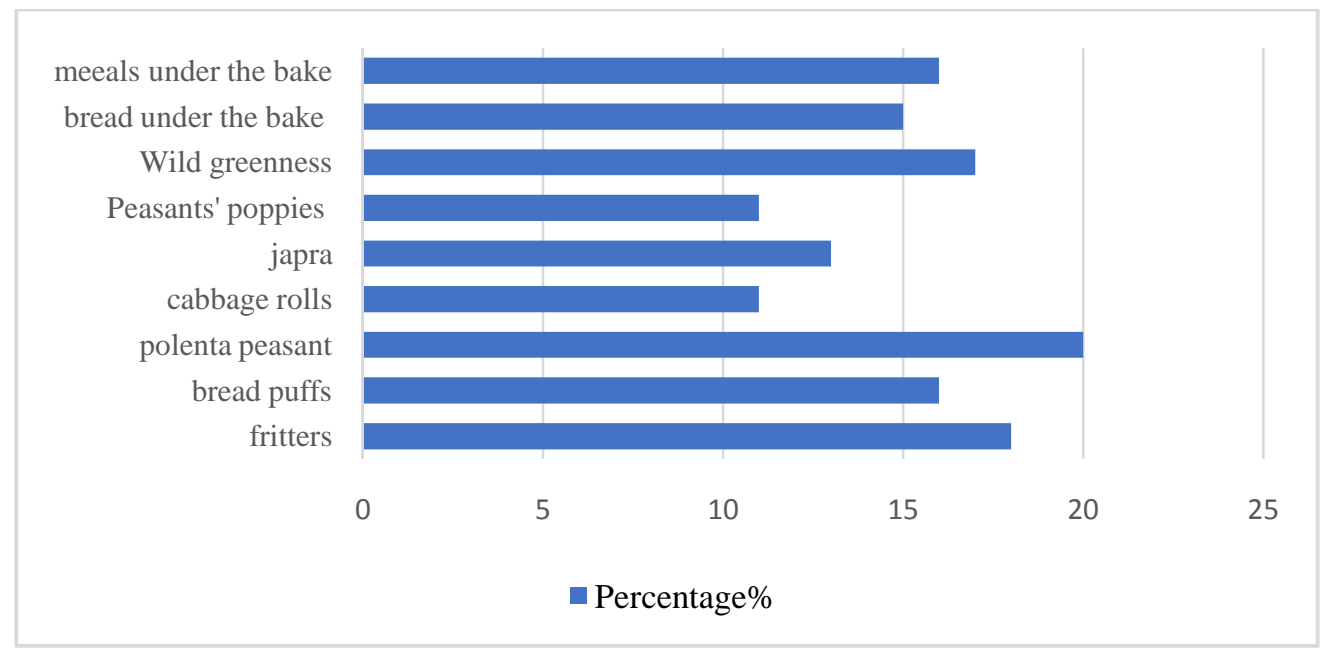

Fig. 4. Representation of some salty traditional products in catering facilities Source: Putica, according to the survey questionnaire 2017.

Most of the gastronomic offer on farms and rural tourism facilities is based on salted dishes, among which the largest share are peas, poultry, meals and bread under the sach, then various kinds of soup such as collorad greens, japrak and others (Fig.4).

Geographical features of Herzegovina have been reflected in the differences in the preparation of the same food at different locations, for example, in the area of Low Herzegovina japrak is made from leaves of vine branches, while on the territory of High Herzegovina is prepared with the leaves of rashtika (collorad greens).

Research has shown that both the space and gastronomy of Herzegovina follows the modern global trends of fast food and the growing share of fast food restaurants, which surprasses some of the traditional specialties from the culinary arts. Traditional sweet products are dominated by hurmasice, patishpanj and various types of pies. (Fig. 5). 


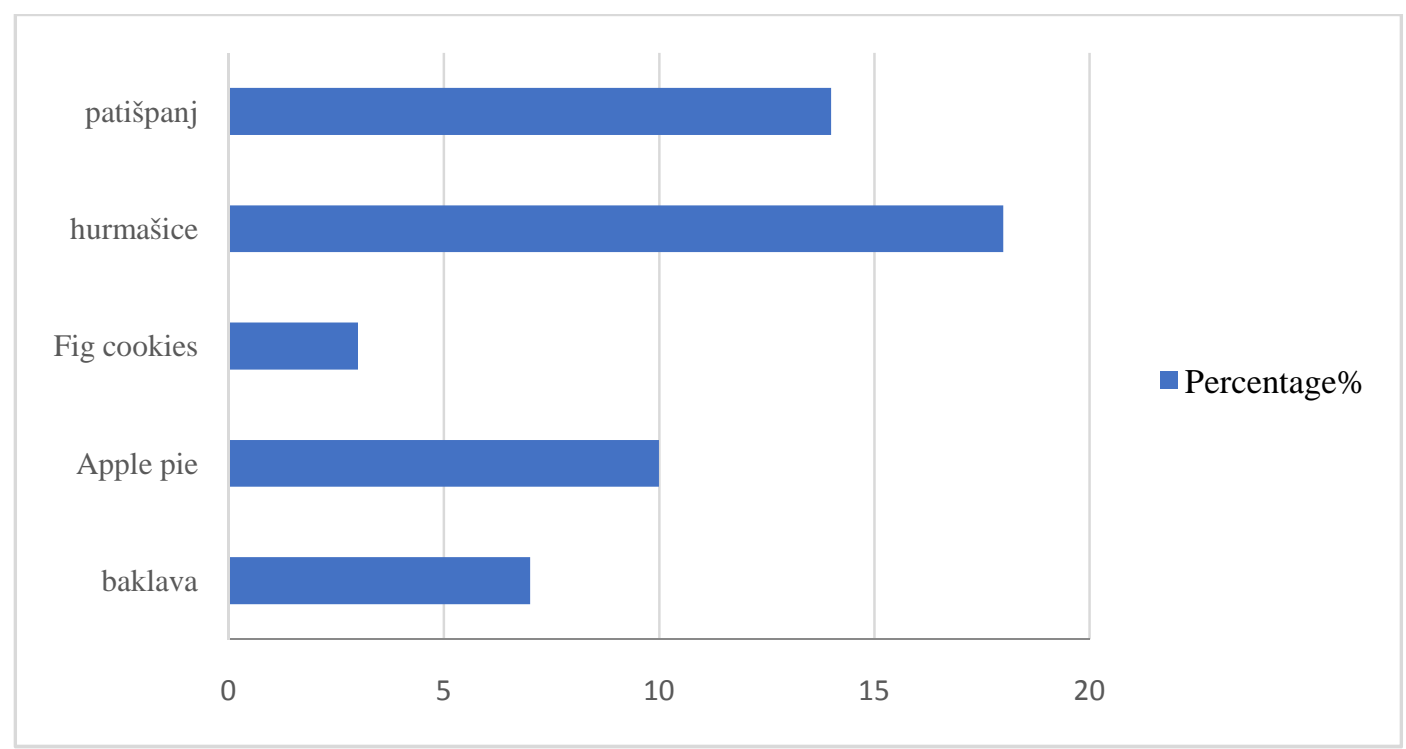

Fig.5.Representation of some sweet traditional products in catering facilities Source: Putica based on survey 2017.

Unfortunately, some of the traditional sweet products like figs, (Fig. 6), grape cakes are all less represented in restaurant dining menus and replaced with sweets like pancakes, muffins and other cakes that are easier to prepare or buy in nearby pastry shops.

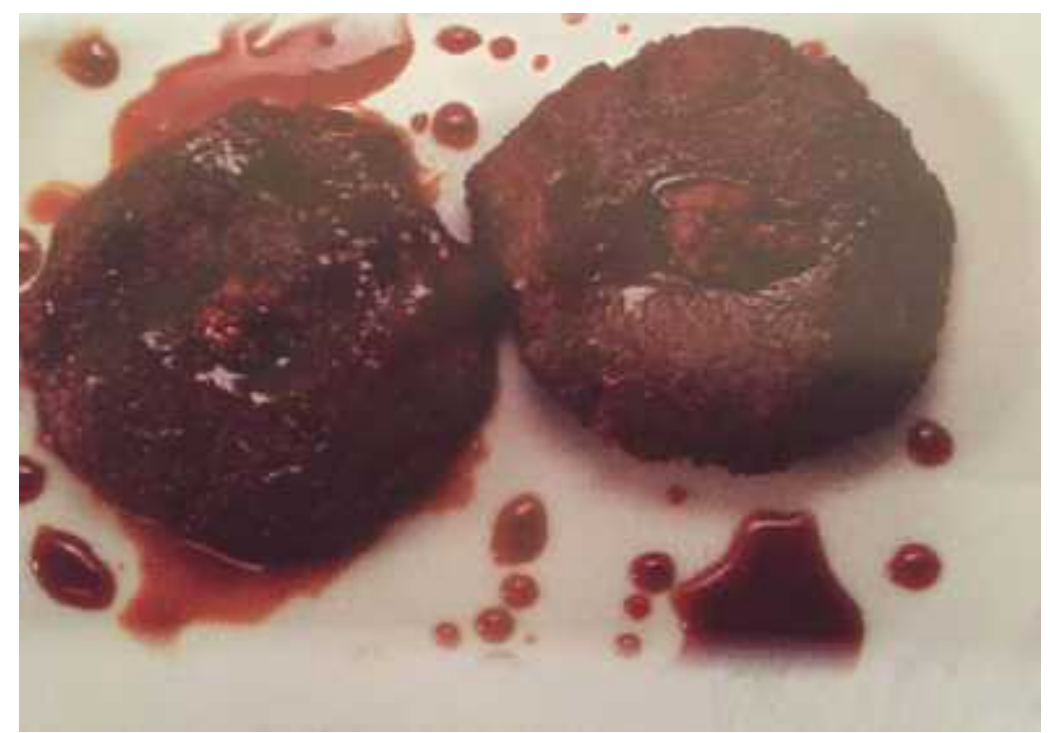

Fig. 6. Cake of fig

Source; Pervan, 2013.

When it comes to traditional beverage offerings, all catering establishments offer wines from indigenous blatina and fennel varieties. $75 \%$ of the objects produce local liqueurs 
and brandy such as „medovača“ honey brandy, „višnjevača“ cherry brandy, ,jabukovača“ apple brandy, „travarica“ herbs brandy, „orahovača“ walnut liquor.

The rest of the survey explored the satisfaction of the tourists with the tourist offer of Herzegovina. According to the country of origin, most of the respondents were $25 \%$ tourists from Italy, (Fig. 7), while the smallest number was from Ireland. The survey was conducted in the summer months, when most tourists visit Medjugorje, which is the leading tourist destination of Herzegovina.

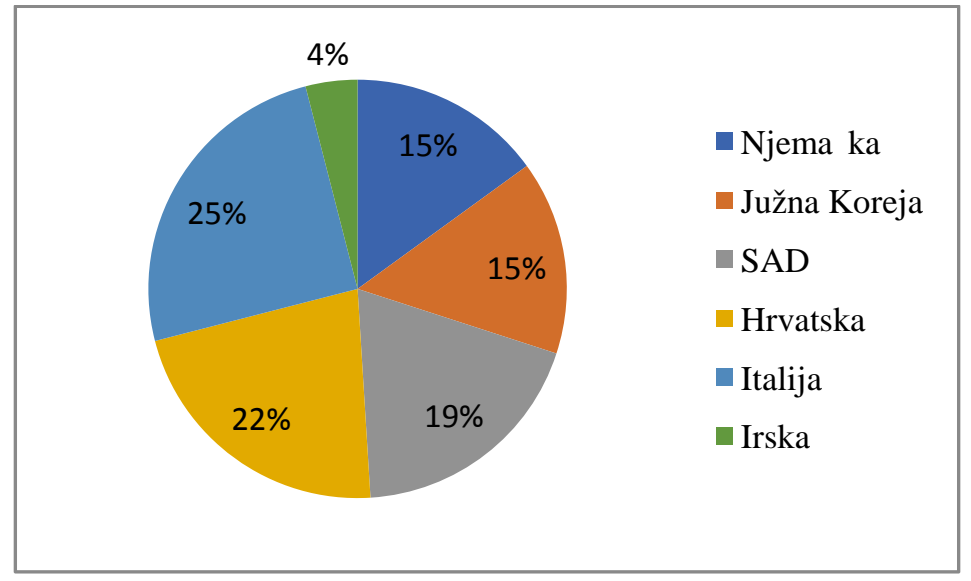

Fig. 7. Structure of respondents by country of origin

Source: Putica, according to surveys, 2017.

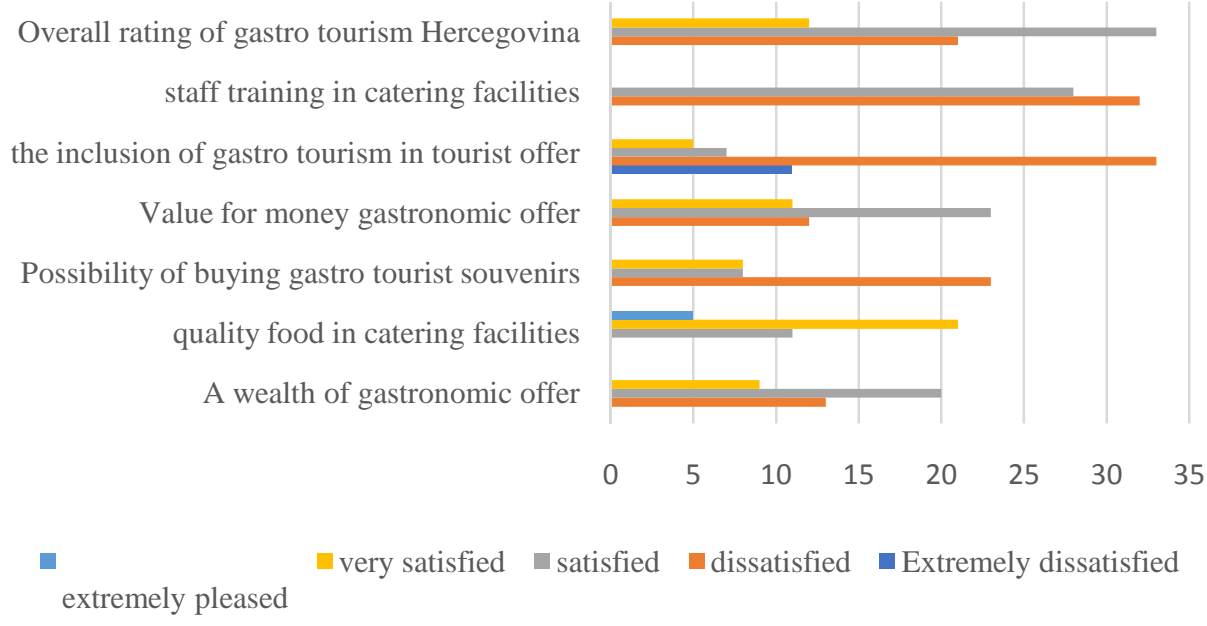

Fig. 8. The pleasure of the elements of the gastro tourist offer of Herzegovina

Source: Authors based on survey 2017.

The satisfaction of respondents was shown using the Likert scale (Fig. 8). The survey showed that the majority of respondents are satisfied and very satisfied with the quality of food in catering facilities, as well as the ratio of price and quality of food. 
The richness of gastronomy has received high marks, which testify to the quality and variety of food offered. Respondents expressed dissatisfaction with the small amount of gastronomic traditional souvenirs in the territory of Herzegovina, as well as the poor inclusion of gastronomy in the tourist offer.

The presented ratings show that Herzegovina as a destination should base its tourism primarily on autochthonous products, in order to be recognized as a gastronomic destination on the tourist market.

\section{CONCLUSION}

Traditional gastronomy is the basic resource for the development of gastronomic tourism in Herzegovina, which has the same importance in rural tourism as in urban tourist destinations. The territory of Herzegovina offers visitors authentic and quality food, but the region is not promoted as a gastronomic tourist destination.

The development of gastronomic tourism would surely contribute to greater protection and branding of certain gastronomic products, such as "pura" and "lučnica", "rashtika", "smokvara", etc. The research also found some other shortcomings such as poor gastronomy involvement in the tourist map of Herzegovina, as well as the lack of gastronomic souvenirs.

Since it is not conditioned by climatic conditions, gastronomy can be a solution for the extension of the tourist season. Connecting catering facilities to wine cellars within the Wine Road of Herzegovina can also contribute to the development of Herzegovina as a recognizable gastronomic destination. The development of gastronomic tourism as part of cultural tourism would also encourage the development of urban destinations that have negligible significance in the tourist offer of Herzegovina. Even, Mostar is not the destination that tourists visit because of recognizable gastronomy.

Geography, due to its interdisciplinarity, connecting natural and social characteristics of the area, plays an important role in gastronomic cultural tourism and determining the particularities of certain foods as a cultural heritage of Herzegovina. At the same time, through food, the local environment opens its potentials to the global tourism market, gastronomy connects agricultural production, crop farming, cattle breeding and service activities and opens up opportunities for educating high-quality staff both in agriculture and in tourism.

\section{REFERENCES}

1. Alibabić, V., Mujić, I., Rudić , D., Bajramović, M., Jokić, S., Šertović, E., (2012): Traditional diets of Bosnia and the representation of the traditional food in the cuisine field, Procedia - Social and Behavioral Sciences 46 ( 2012 ) 1673 - 1678. 
2. Cavicchi, A. and K., Ciampi Stancova, (2016); Food and gastronomy as elements of regional innovation strategies. European Commission, Joint Research Centre, Institute for Prospective Technological Studies, Spain. EUR 27757 EN; doi:10.2791/284013

3. Drpić, K., Vukman, M., (2014): Gastronomija kao važan dio turističke ponude u Hrvatskoj, Praktični menadžment, Vol. V., br. 1., str. 62-67.

4. Halilović-Šarić, E. (2015)Tradicionalna bosanska hrana, Baština sjeveroistočne Bosne VII, 2014, Tuzla, 2015., 83. - 92.

5. Hall, C.M. (2012). Boosting food and tourism-related regional economic development. In OECD, Food and the Tourism Experience: The OECD-Korea Workshop, OECD Studies on Tourism, OECD Publishing: 49-62.

6. Hall, C.M. and Sharples, L. (2008): The consumption of experiences or the experience ofconsumption? An introduction to the tourism of taste in Food and Wine Festivals and Events around the World: Development, Management and Markets. Butterworth Heinemann, (editors : Hall, Sharples, Mitchell, Macionis, Cambourne), Oxford., pp 390.

7. Jiménez-Beltrán, J. F. , López-Guzmán, T., González Santa Cruz, F. (2016): Analysis of the Relationship between Tourism and Food Culture Sustainability, 2016, 8, 418; doi:10.3390/su8050418., pp 1-11.

8. Kalenjuk, B., Tešanović, D., Gagić, S., Vuksanović,N., Škrinjar, M. (2013.) Tourists manifestations in the development of culinary tourism in Banat (Vojvodina, Serbia) Geographica Timisiensis, Romania, on line first, 2013.

9. Kalit, S. ( 2016): Proizvodnja ovčjih $i$ kozjih sireva od sirovog mlijeka, EUADCBIH, str.32.

10. Kempiak, J. ,Hollywood, L., Bolan, P., and Gilmoreb, A., (2012.): Digital marketing and food tourism: towards a better understanding of food tourists' engagement, World Tourism Organisation (WTO) (2012). Global report on food tourism. UNWTO, Madrid.

11. Long, L. M. (2004), Culinary tourism: A folkloristic on eating and otherness, Lexington, K.Y.: The University Press of Kentucky, 20-50.

12. Ministarstvo kulture Republike Hrvatske (2007): Rješenje Ministarstva kulture za uspostavljanje svojstva nematerijalnog kulturnog dobra, Klasa: UP-Io 61208/07-06/0374, Urbroj: 532-04-02-02/2-07-2, Zagreb, 20. prosinca 2007.

13. Quan, S. and Wang, N. (2004) 'Toward a structural model of the tourist experience: an illustration from food experiences in tourism', Tourism Management, Vol. 25, pp.297-305.

14. Pervan. P. (2013) Tradicionalna hercegovačka jela $i$ vina, STUŠ, Mostar.

15. Richards, G. (2015). Food experience as integrated destination marketing strategy. Paper presented at the World Food Tourism Summit in Estoril, Portugal, April 10th, 2015. 
16. Tikkanen, I. (2007) 'Maslow's hierarchy and food tourism in Finland: five cases', British Food Journal, Vol. 109, No. 9, pp.721-734.

17. Williams, A., H:, Williams, L. R. Jr. and Omar, M. (2014): Gastro-tourism as destination branding in emerging markets Int. J. Leisure and Tourism Marketing, Vol. 4, No. 1, 2014 , pp.1 - 18 DOI: 10.1504/IJLTM.2014.059257 